\title{
Application of AHP for Supplier Selection in Construction Companies
}

\author{
Rosalendro Eddy Nugroho ${ }^{1 *}$, Maria Sherly Iskandar ${ }^{2}$ \\ Mercu Buana University, Jalan Meruya Selatan No.1 Jakarta Barat - Indonesia
}

DOI: $10.36348 /$ sjet.2020.v05i04.008

| Received: 06.04.2020 | Accepted: 24.04.2020 | Published: 30.04 .2020

*Corresponding author: Rosalendro Eddy Nugroho

\section{Abstract}

The procurement process is an important process in supply chain management as it is the spearhead of the entire process. In carrying out the procurement process, there are often problems with the supplier selection activities. This is because the supplier selection process spends a lot of time and resources collecting data and conducting careful analysis that will affect the entire decision alternative. In making decisions relating to the many criteria and the number of alternative suppliers, it requires an effective and uncomplex assessment technique, but it provides accurate results. A mapping and determination of supplier selection criteria is required as a basis for valuation to obtain a qualified supplier. This study focused on PT. XYZ is a construction company in South Tangerang. Analytical Hierarchy Process (AHP) is used to determine the best supplier; there are 4 variables that are reference in conducting the selection of suppliers, such as: cost, quality, delivery, and service. The result in the selection of the supplier company is cost with a weight of 0.268 , quality with a weight of 0.290 , delivery with a weighting of 0.248 , and the service with a weight of 0.194 where conclusions obtained from the analysis of the selection of the best suppliers and in accordance with the criteria, namely PT. CBL for iron suppliers, PT.SAS for cement suppliers, and PT. Citra BSD for suppliers of natural materials.

Keywords: AHP, supply chain, procurement, supplier selection, project, construction.

Copyright @ 2020: This is an open-access article distributed under the terms of the Creative Commons Attribution license which permits unrestricted use, distribution, and reproduction in any medium for non-commercial use (NonCommercial, or CC-BY-NC) provided the original author and source are credited.

\section{INTRODUCTION}

Procurement is a process to obtain useful goods and services to ensure the smooth production process and logistics of a company. The procurement process is an important process in supply chain management as it is the spearhead of the entire process. In conducting procurement process, there are often problems in the activity of selection of suppliers that will affect the whole alternative decision [2]. Therefore, it takes methods that can be used to help the supplier selection process. The selection of suppliers needs to consider many criteria, therefore the supplier evaluation process requires a multi-criteria approach in the analysis and retrieval of solutions [4]. Once the criteria are established and some candidates are acquired, the company must make the selection. The company may choose one or more of the existing alternatives. In this election the company may have to do a step to determine which supplier to choose or which will be used as the main supplier and which will be used as a spare supplier. One method that is quite common used in the preferred alternative to the number of criteria is the Analytical Hierarchy Process (AHP). AHP method is often used in decision making where, the decision to be chosen consists of various kinds of complex. AHP also considers any existing choice according to the expert on related issues. In AHP method the process of complex decision making, will be simplified by lowering the problem into the framework of hierarchy and divide into structured parts to easily identify and find the way out [10].

\section{LITERATURE REVIEW Supply Chain Management}

Supply Chain Management (SCM) is not only oriented to the internal affairs of a company, but also external affairs relating to the relationship with the partner companies with an approach integrating the supplier, manufacturer, distribution center, wholesaler, retailer (retailer), and customer, where the product is manufactured and Distributed in correct quantities, precise location and timing to minimize costs and increase customer satisfaction [1]. Because companies that are in a supply chain in essence want to satisfy the consumers of the same end, they must work together to make the product acceptable to the customer, in order to supply chain of goals can be achieved.

SCM can improve the competitive ability for the overall supply chain, but does not cause a long-term 
sacrifice. It is therefore necessary to clear understanding, belief, and play rules. It is important to maintain ethics for those who want a strong supply chain in the long term. In the concept of supply chain, suppliers are one of the most important and influential part of the company's life continuity. When we refer to a manufacturing company, the main activities that are included in the

\section{SCM classification is \\ 1. Product development \\ 2. Procurement, purchasing or supply \\ 3. Inventory planning and control \\ 4. Production \\ 5. Distribution \\ 6. Product Return}

SCM requires a robust approach and management model to stay in the business world. The above is coupled with various rules or demands in the government and community to maintain the environmental aspects in the supply chain activities. One of the major challenges in the management of supply chain is that Ketidkpastian can come from the direction of demand, supplier, or internal company.

\section{Procurement}

Procurement management is providing inputs in the form of goods or services needed in production activities or other activities within the company. In manufacturing companies, goods that must be purchased by procurement parts can be classified generally into raw materials production needs, capital equipment such as machinery, and other long-term equipment, machinery parts and stationery office. Along with the increasing demands of the customer and the short of the product life cycle in various sectors of industry, the mixing part is also required to be able to create an advantage in terms of time. As one of the important factors in competing, the time can be very determined whether or not supply chain in the fight in the market.

\section{The general procurement duties include}

1. Designing the right relationships with suppliers. These relationships are long-term partnerships and short-term transactional relationships. The Procurement Section is tasked to design a relationship portfolio for all suppliers.

2. Choosing a supplier. The activity of choosing a supplier can take time and resources not less if the supplier is a key supplier.

3. Choose and implement suitable technology. Procurement activities always require technological assistance. Nowadays, many companies use electronic procurement.

4. Maintain data on required items and supplier data. The Procurement section must have full data on the required items as well as data about the supplier.

5. Make a purchase. This is the most routine work done by the Procurement Section. Purchases can be routinely or through tender or auction.

6. Evaluate supplier performance. This performance assessment is very important to create a sustainable competitiveness. Assessment results can also be used as a supplier input to improve their performance.

\section{Supplier Selection}

In supply chain management, supplier selection decisions are generally regarded as one of the most significant in the responsibilities of managers [6]. To maintain a competitive edge in global markets, organisations should consider environmental issues and embrace the supplier selection evaluation model. Supplier selection decisions can be applied in many situations such as many supplier cases, as well as in various stages of life cycle products from the initial raw material purchase to the end of the service provider [3].

\section{The main factor considered by a company when choosing a supplier is [13]}

1. Price factors are usually a major factor, whether there is a discount offer, even though it is sometimes not the most important thing.

2. The quality of a company may cost you more to improve the quality of good goods.

3. Special services sometimes can be important in the selection of suppliers. Replacement of damaged goods, instructions for use, repair of equipment and similar services, can be a key in the selection of one supplier than the other.

4. Location of the supplier can have an influence on the delivery time, transportation costs, and response time when there are sudden orders/orders or emergency services. Purchasing in local/local areas can foster goodwill in a relationship and can help the area's economy.

5. Supplier Inventory policy Suppliers if the supplier can maintain its policy and maintain its spare part, it can help in case of sudden raw material needs.

6. The flexibility of good responses and the supplier's ability to respond to changes in demand and meet changes in order design can be an important factor in the selection of suppliers.

The hierarchy is defined as a representation of a complex problem in a multi-level structure, where the first level is goal followed by the level of factors, criteria, sub-criteria, and so on to To the last level of the alternative. With a hierarchy, a complex problem can be outlined into Kelompok-kelompoknya which is then set to be a form of hierarchy so that the problem will appear more structured and systematic.

\section{Supplier Selection Criteria}

Selection criteria are one of the key things in supplier selection. The criteria used must necessarily reflect the supply chain strategy as well as the characteristics of the items to be supplied. In general, 
many companies use basic criteria such as the quality of goods offered, prices, and timeliness of delivery. However, often supplier selection requires various other criteria that the company considers important.

Supplier selection decisions should be considered well because suppliers can make an impact on the company, whether it is a positive impact or a negative impact on the company's performance. Therefore, a supplier's selection, management, and evaluation process is required. Criterion is one of the factors that can be used in selecting and evaluating Suppliers [8], then the criteria is important to be determined so that the company can choose the best supplier.

Supplier selection plays an important role in the company's supply chain process. Companies must work with different suppliers to perform their activities so that components and spare parts can be delivered on time. Supplier selection is a problem of multi-criterion decision Making (MCDM) [15]. The main factors considered by a company when choosing a supplier are price, quality, service, location, supplier inventory policy and flexibility [13]. There are 22 criteria for supplier selection [5]:

Table-1: Criteria in Supplier Selection

\begin{tabular}{|l|l|}
\hline Criteria & Score \\
\hline Quality & 3.5 \\
\hline Delivery & 3.4 \\
\hline Performance History & 3.0 \\
\hline Warranties and Claim Policies & 2.8 \\
\hline Price & 2.8 \\
\hline Technical Capability & 2.8 \\
\hline Financial Position & 2.5 \\
\hline Procedural Compliance & 2.5 \\
\hline Communication System & 2.5 \\
\hline Reputation and Position in Industry & 2.4 \\
\hline Desire for Business & 2.4 \\
\hline Management and Organization & 2.3 \\
\hline Operating Control & 2.2 \\
\hline Repair Service & 2.2 \\
\hline Attitude & 2.1 \\
\hline Impression & 2.1 \\
\hline Packaging Ability & 2.0 \\
\hline Labor Relation & 2.0 \\
\hline Geographical Location & 1.9 \\
\hline Amount of Past Business & 1.6 \\
\hline Training Aids & 1.5 \\
\hline Reciprocal Arrangement & 0.6 \\
\hline
\end{tabular}

(Source: Dickson, 1966; Pujawan, 2017)

\section{Analytical Hierarchy Process}

The Analytical Hierarchy Process (AHP) is one of the methods in the decision-making system that uses multiple variables with a multilevel analysis process $[11,9]$. The analysis is done by giving the priority value of each variable, then comparing pairs of variations of variables and alternatives [14]. The AHP is a functional model of the hierarchy with the primary input being human perception. AHP is a decisionmaking method developed to solve problems by finding solutions to problems, grouping and then putting them into a hierarchical structure. To obtain the prioritized criteria, this method uses a comparison of paired criteria with a predefined measurement scale. The primary Input of AHP method is the perception of experts or experts, so there is a subjectivity factor in decision making.
The steps and procedures in resolving the problems that are Kom-Pleks using AHP method are as follows:

1) Defining problems and determining objectives

2) Create a hierarchy

The problem is arranged in a hierarchy that begins with a general purpose, followed by subobjectives, criteria, and possible alternatives at the bottom of the criteria level.

3) Do a comparison pair (pairwise comparison).

The comparison is based on "Judgement" from decision makers by assessing the importance of an element compared to other elements. The comparison matrix can be seen in table 2.4. This matrix illustrates the relative contribution or influence of each element to 
each of the above objectives or criteria. Where the value of comparison $A_{i}$ against the $A_{j}$ element is $a_{i j}$. A value is determined by the rule: a) if $\mathrm{a}_{\mathrm{ij}}=\alpha$, then $\mathrm{ji}_{\mathrm{ji}}=1 / \alpha, \alpha \neq 0$.

b) If $\mathrm{Ai}$, have the same level of relative importance of $A_{j}$, then $a_{i j}=a_{j i}=1$.

c) The special thing, $a_{\mathrm{ii}}$ for all $\mathrm{i}$.

Table-2: Pairwise Comparison Matrix

\begin{tabular}{|l|l|l|l|l|}
\hline Criteria & A1 & A2 & $\ldots .$. & An \\
\hline A1 & a11 & a12 & $\ldots \ldots$ & a1n \\
\hline A2 & a21 & a22 & $\ldots \ldots$ & a2n \\
\hline$\ldots \ldots$ & $\ldots \ldots$ & $\ldots \ldots$ & $\ldots \ldots$ & $\ldots \ldots$ \\
\hline An & an1 & an2 & $\ldots .$. & ann \\
\hline & & & & \\
\hline
\end{tabular}

(Source: Saaty, 1994)

The comparison is done until judgement is obtained entirely by $\mathrm{n} \mathrm{X}[(\mathrm{n}-1) / 2]$ pieces, with $\mathrm{n}$ being the number of elements being compared.

\section{4) Determining priorities}

Priority drafting is done for each element of the problem at the hierarchy level. This process will result in weighting or contributing criteria to achieve the objectives. Priorities are determined by the highest weighted criteria. The desired weight is expressed in the eigen vector $\mathrm{W}=\left(\mathrm{W}_{1}, \mathrm{~W}_{2}, \ldots, \mathrm{W}_{\mathrm{n}}\right)$. The $\mathrm{W}_{\mathrm{n}}$ value stated is the relative weight of the criteria $A_{n}$ for the overall set of criteria on sub-systems.

5) Consistency Index (CI)

$$
C I=\frac{(\lambda \max -n)}{(n-1)}
$$

Where:

$\lambda \max =$ largest value of Eigen in matrix order $n$

$$
\mathrm{n} \quad=\text { number of criteria }
$$

Consistency Ratio (CR)

$$
C R=\frac{C I}{R I}
$$

Where:

$$
\begin{array}{lr}
\text { CI } & =\text { Index Consistency } \\
\text { CR } & =\text { Consistency Ratio } \\
\text { RI } & =\text { Random Index }
\end{array}
$$

Table-3: Random Index (RI)

\begin{tabular}{|c|c|c|c|c|c|c|c|c|c|}
\hline $\mathrm{N}$ & 1 & 2 & 3 & 4 & 5 & 6 & 7 & 8 & 9 \\
\hline $\mathrm{RI}$ & 0 & 0 & 0.58 & 0.9 & 1.12 & 1.24 & 1.32 & 1.41 & 1.45 \\
\hline
\end{tabular}

(Source: Saaty, 1998)

When the pairwise/comparison matrix has a value of $\mathrm{CR}<0.10$ then the inconsistency of the opinions of decision makers is acceptable, and if the value is not met then the assessment should be repeated. Weights for group assessments are stated by finding geometric mean:

$$
\mathrm{GM}=\sqrt[n]{(x 1) \cdot(x 2) \ldots .(\mathrm{xn})}
$$

$$
\begin{array}{ll}
\text { Where: } & \\
\text { GM } & =\text { Geometric Mean } \\
\mathrm{X}_{1} & =\text { responden } 1 \\
\mathrm{X}_{2} & =\text { responden } 2 \\
\mathrm{Xn} & =\text { responden }-\mathrm{n} \\
\mathrm{n} & =\text { total of responden }
\end{array}
$$

\section{RESEARCH METHODOLOGY}

Supported qualitative method because the research is done through field observations with the dissemination of questionnaires and interviews directly on the director of engineering, project manager, supervisor procurement, staff quantity surveyor, and field coordinator, to obtain other important information about the factors used in the selection of suppliers. Meanwhile, there are as many as 7 supplier companies. The criteria used in the selection of suppliers are as follows:

1. Cost, includes 3 sub-criteria :

(C1) Material Price

(C2) Discount Price

(C3) Payment Deadlines

2. Quality, includes 3 sub-criteria :

(Q1) Accuracy of Material Type

(Q2) Material Strength

(Q3) Ability to Deliver Consistent Quality

3. Delivery, includes 3 sub-criteria :

(D1) Timely Delivery

(D2) Accuracy of Shipment Amount

(D3) Transportation Handling Capability

4. Service, includes 6 sub-criteria :

(S1) Warranty 
(S2) Quick Response in Handling Customer Request

(S3) Quick Response to Customer Complaints Handling

(S4) Ability to Provide Product Information Clearly
(S5) Fast and Precise Handling of Material Volume Change Requests

(S6) Fast and Precise Handling Request Change of Material Booking Time

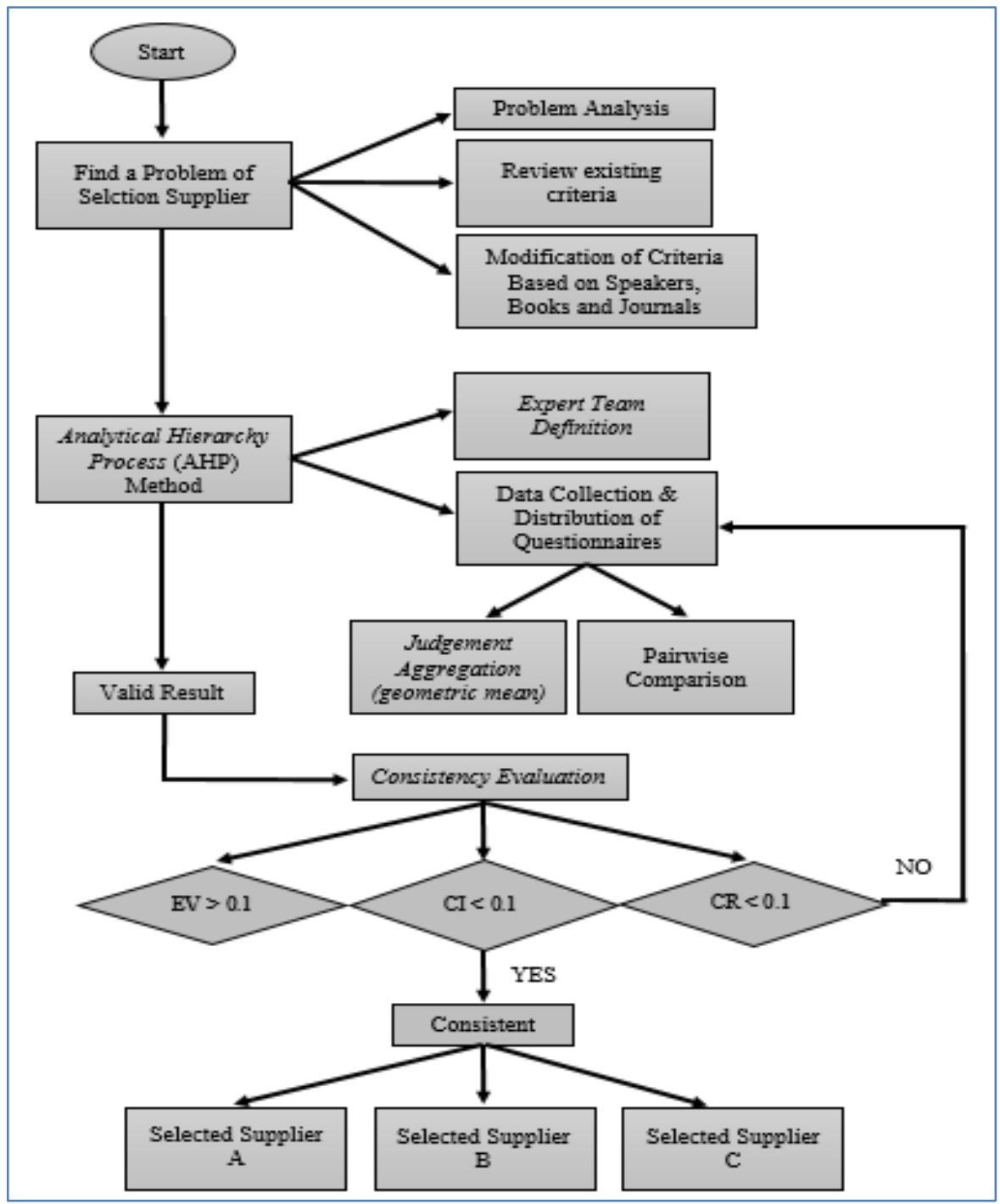

Fig-1: Diagrammatic Representation of the Research Workflow

The non-probability sampling technique used in this study is a sampling purposive technique of sampling techniques with certain considerations. The reason the sample selection by using purposive sampling is because not all of the samples have the criteria corresponding to which the authors specify. This is because the AHP method hints at the respondent according to the type of specialist concerned in decision making. In addition, respondents must also have sufficient knowledge and experience about the problem. Primary data retrieval is done by completing questionnaire and interview. This is done by spreading the questionnaire, discussion and direct questioning to get the data. And secondary data is derived from data procurement process in XYZ Enterprise system, through the literature on supllier selection, and other previous re-search related to the research.

\section{RESULTS AND DISCUSSION}

Based on interviews with the Technical Director, Project Manager, Procurement Supervisor, Quantity Surveyor Staff, and Field Coordinator, it was found that all suppliers offer similar prices. This implies that the price criterion is no longer relevant to be used as a basis in selecting suppliers. Based on some historical data, it is agreed that there are four criteria to be used in the selection of suppliers, i.e. cost, quality, delivery, and services.

\section{Structuring the Hierarchy}

This figure shows the hierarchy for the supplier decision model. 


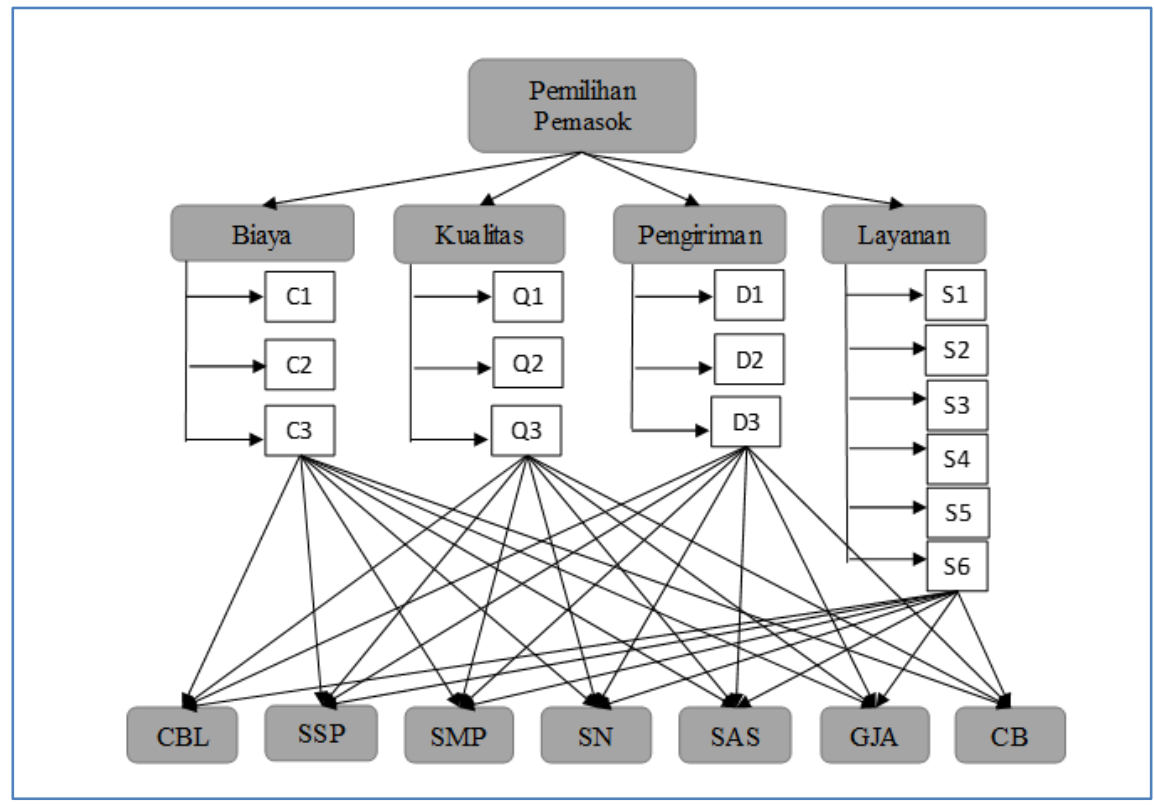

Fig-2: A Hierarchical Representation of the AHP Model

\section{Performing Pairwise Comparisons}

After constructing the hierarchy, pairwise comparisons were performed systematically throughout the structure. Prior to our study, we hoped that we would be able to go through the pairwise comparisons together with the decision making team. It was not possible due to differences among the schedule of the managers. Hence, 105 questions questionnaires including all possible pairwise comparison combinations were distributed to the decision-making team.

\begin{tabular}{|l|r|r|r|r|}
\hline & \multicolumn{2}{|c|}{ Biaya (Cost } & Kualitas (Q) & Pengiriman \\
\hline Biaya (Cost) & & $(1,03131)$ & $(1,05922)$ & 1,52198 \\
\hline Kualitas (Quality) & & & 1,08447 & 1,71877 \\
\hline Pengiriman (Delivery) & & & & 1,03131 \\
\hline Layanan (Service) & Incon: 0,01 & & & \\
\hline
\end{tabular}

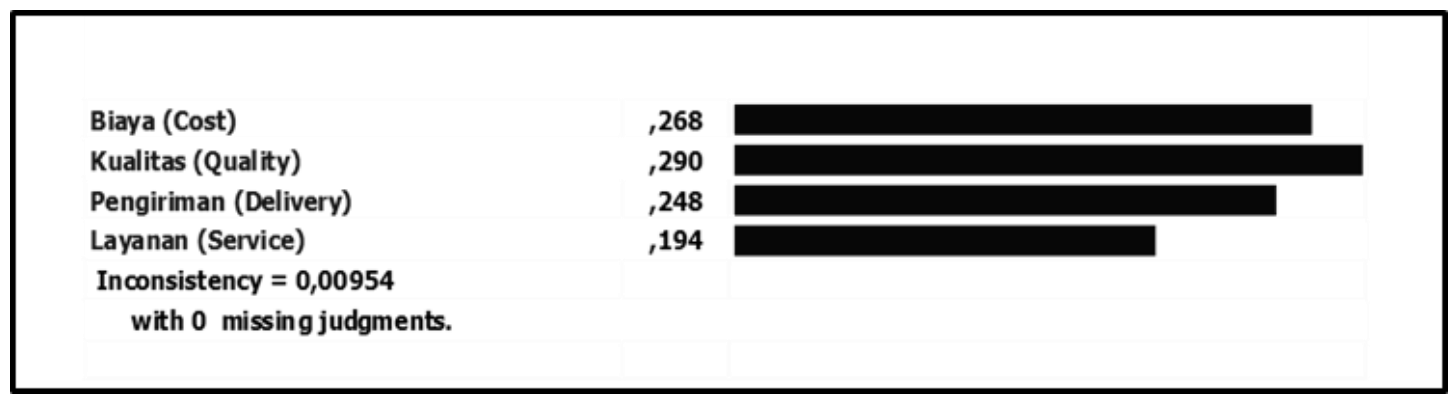

Fig-3: Comparing Major Criteria -Judgments and Resulting Weights of Major Criteria

\begin{tabular}{|c|c|c|c|c|c|c|c|c|c|c|c|c|c|c|c|}
\hline \multirow{4}{*}{ Goal (0) } & \multirow{4}{*}{ Criteria (I) } & \multirow{4}{*}{ Weights } & \multirow{4}{*}{ Priority } & \multirow{4}{*}{$\begin{array}{l}\text { Subcriteria } \\
\text { (II) }\end{array}$} & \multirow{4}{*}{ Weights } & \multirow{4}{*}{ Priority } & \multicolumn{9}{|c|}{ Supplier Alternatives } \\
\hline & & & & & & & \multicolumn{9}{|c|}{ (III) } \\
\hline & & & & & & & \multicolumn{3}{|c|}{ Iron } & \multicolumn{3}{|c|}{ Cement } & \multicolumn{3}{|c|}{ Natural Material } \\
\hline & & & & & & & Alt & Weight & Priority & Alt & Weight & Priority & Alt & Weigh & Priority \\
\hline \multirow{9}{*}{$\begin{array}{c}\text { Best } \\
\text { Supplier }\end{array}$} & \multirow{9}{*}{ Cost } & \multirow{9}{*}{0,268} & \multirow{9}{*}{ II } & \multirow{3}{*}{$\mathrm{C} 1$} & & & CBL & 0,384 & II & SMP & 0,424 & II & GIA & 0,162 & II \\
\hline & & & & & 0,274 & II & SSP & 0,616 & I & SN & 0,134 & III & $\mathrm{CB}$ & 0,838 & I \\
\hline & & & & & & & & & & SAS & 0,442 & I & & & \\
\hline & & & & \multirow{3}{*}{$\mathrm{C} 2$} & & & CBL & 0,440 & II & SMP & 0,303 & II & GIA & 0,216 & II \\
\hline & & & & & 0,115 & III & SSP & 0,560 & I & SN & 0,218 & III & $C B$ & 0,784 & I \\
\hline & & & & & & & & & & SAS & 0,479 & I & & & \\
\hline & & & & \multirow{3}{*}{ C3 } & & & $\mathrm{CBL}$ & 0,873 & I & SMP & 0,307 & II & GIA & 0,127 & II \\
\hline & & & & & 0,611 & I & SSP & 0,127 & II & SN & 0,123 & III & $\mathrm{CB}$ & 0,873 & I \\
\hline & & & & & & & & & & SAS & 0,570 & I & & & \\
\hline
\end{tabular}

Fig-4: Priorities of Cost Criteria and Alternatives Supplier 


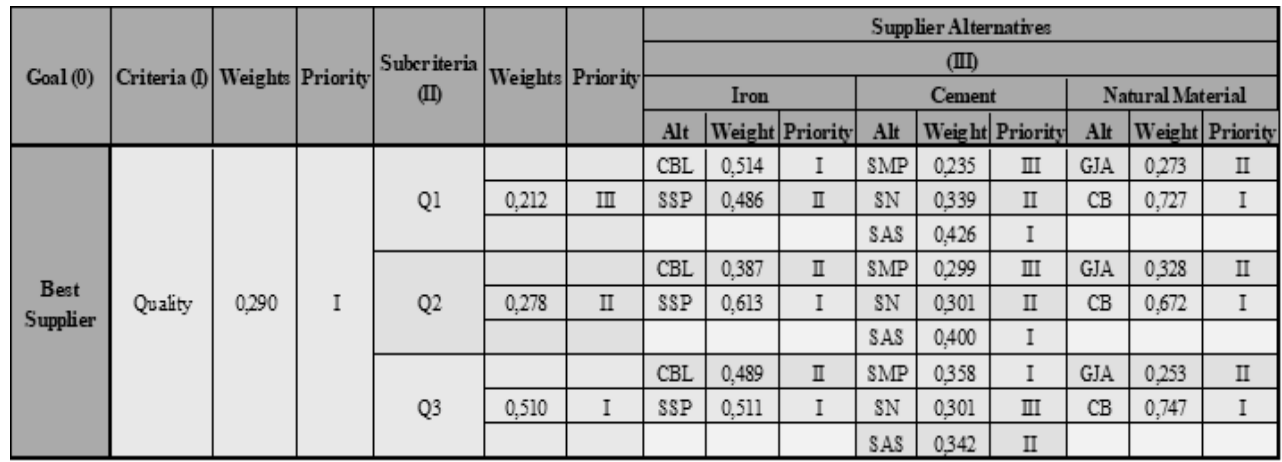

Fig-5: Priorities of Quality Criteria and Alternatives Supplier

\begin{tabular}{|c|c|c|c|c|c|c|c|c|c|c|c|c|c|c|c|}
\hline \multirow{4}{*}{ Goal (0) } & \multirow{4}{*}{ Criterin (I) } & \multirow{4}{*}{ Weights } & \multirow{4}{*}{ Priority } & \multirow{4}{*}{$\begin{array}{l}\text { Subcriteria } \\
\text { (II) }\end{array}$} & \multirow{4}{*}{ Weights } & \multirow{4}{*}{ Priority } & \multicolumn{9}{|c|}{ Supplier Alternatives } \\
\hline & & & & & & & \multicolumn{9}{|c|}{ (III) } \\
\hline & & & & & & & \multicolumn{3}{|c|}{ Iron } & \multicolumn{3}{|c|}{ Cement } & \multicolumn{3}{|c|}{ Natural Material } \\
\hline & & & & & & & Alt & Weight & Priority & Alt & Weight & Priorit & Alt & Weight & Priorit \\
\hline \multirow{9}{*}{$\begin{array}{l}\text { Best } \\
\text { Supplier }\end{array}$} & \multirow{9}{*}{ Delivery } & \multirow{9}{*}{0,248} & \multirow{9}{*}{ III } & \multirow{3}{*}{ D1 } & & & $\mathrm{CBL}$ & 0,659 & I & $\mathrm{SMP}$ & 0,264 & II & GJA & 0,289 & II \\
\hline & & & & & 0,371 & II & SSP & 0,341 & II & SN & 0,225 & III & $C B$ & 0,711 & I \\
\hline & & & & & & & & & & SAS & 0,511 & I & & & \\
\hline & & & & \multirow{3}{*}{ D2 } & & & $\mathrm{CBL}$ & 0,420 & II & SMP & 0,365 & $\mathrm{I}$ & GIA & 0,246 & II \\
\hline & & & & & 0,475 & I & SSP & 0,580 & I & SN & 0,332 & II & $C B$ & 0,754 & $\mathrm{I}$ \\
\hline & & & & & & & & & & SAS & 0,303 & III & & & \\
\hline & & & & \multirow{3}{*}{ D3 } & & & CBL & 0,679 & I & SMP & 0,398 & I & GJA & 0,458 & II \\
\hline & & & & & 0,154 & III & SSP & 0,321 & II & SN & 0,301 & II & $\mathrm{CB}$ & 0,542 & I \\
\hline & & & & & & & & & & SAS & 0,301 & III & & & \\
\hline
\end{tabular}

Fig-6: Priorities of Delivery Criteria and Alternatives Supplier

\begin{tabular}{|c|c|c|c|c|c|c|c|c|c|c|c|c|c|c|c|}
\hline \multirow{4}{*}{ Goal $(0)$} & \multirow{4}{*}{ Criteria (I) } & \multirow{4}{*}{ Weights } & \multirow{4}{*}{ Priority } & \multirow{4}{*}{$\begin{array}{l}\text { Subcriteria } \\
\text { (II) }\end{array}$} & \multirow{4}{*}{ Weights } & \multirow{4}{*}{ Priority } & \multicolumn{9}{|c|}{ Supplier Alternatives } \\
\hline & & & & & & & \multicolumn{9}{|c|}{ (III) } \\
\hline & & & & & & & \multicolumn{3}{|c|}{ Iron } & \multicolumn{3}{|c|}{ Cement } & \multicolumn{3}{|c|}{ Natural Material } \\
\hline & & & & & & & Alt & Weight & Priority & Alt & Weight & Priority & Alt & Weight & Priority \\
\hline \multirow{18}{*}{$\begin{array}{c}\text { Best } \\
\text { Supplier }\end{array}$} & \multirow{18}{*}{ Services } & \multirow{18}{*}{0,194} & \multirow{18}{*}{ IV } & \multirow{3}{*}{ s1 } & & & $\mathrm{CBL}$ & 0,575 & I & SMP & 0,279 & III & GIA & 0,357 & II \\
\hline & & & & & 0,162 & II & SSP & 0,425 & II & SN & 0,341 & II & $C B$ & 0,643 & I \\
\hline & & & & & & & & & & SAS & 0,407 & I & & & \\
\hline & & & & \multirow{3}{*}{$\$ 2$} & & & CBL & 0,622 & I & SMP & 0,248 & III & GIA & 0,216 & II \\
\hline & & & & & 0,154 & IV & SSP & 0,378 & II & SN & 0,278 & II & $C B$ & 0,784 & I \\
\hline & & & & & & & & & & SAS & 0,473 & I & & & \\
\hline & & & & \multirow{3}{*}{ \$3 } & & & $\mathrm{CBL}$ & 0,772 & I & SMP & 0,381 & II & GIA & 0,295 & II \\
\hline & & & & & 0,317 & I & SSP & 0,228 & II & SN & 0,202 & III & $\mathrm{CB}$ & 0,705 & I \\
\hline & & & & & & & & & & SAS & 0,417 & I & & & \\
\hline & & & & \multirow{3}{*}{$\$ 4$} & & & CBL & 0,500 & I & SMP & 0,407 & I & GIA & 0,304 & II \\
\hline & & & & & 0,065 & $\mathrm{VI}$ & SSP & 0,500 & II & SN & 0,300 & II & $C B$ & 0,696 & I \\
\hline & & & & & & & & & & SAS & 0,292 & III & & & \\
\hline & & & & \multirow{3}{*}{ s5 } & & & CBL & 0,705 & I & SMP & 0,259 & III & GIA & 0,376 & II \\
\hline & & & & & 0,157 & III & SSP & 0,295 & II & SN & 0,278 & II & $\mathrm{CB}$ & 0,624 & I \\
\hline & & & & & & & & & & SAS & 0,463 & I & & & \\
\hline & & & & \multirow{3}{*}{ \$6 } & & & CBL & 0,747 & I & SMP & 0,320 & II & GIA & 0,401 & II \\
\hline & & & & & 0,145 & $\mathrm{~V}$ & SSP & 0,253 & II & SN & 0,257 & III & $C B$ & 0,599 & I \\
\hline & & & & & & & & & & SAS & 0,423 & I & & & \\
\hline
\end{tabular}

Fig-7: Priorities of Services Criteria and Alternatives Supplier

There are 4 criteria used in this research, the highest weight criteria that can be referenced by the company in choosing the Supplier is quality (weight of interest 29\%), hereinafter the cost (interest 26.8\%), delivery (weight of interest $24.8 \%$ ) and services (weight of interest 19.4\%). Data analysis result from AHP calculation, obtained using a questionnaire of 5 respondents, stating that the alternative selection of each main material selected and best according to the criteria, for the iron supplier is PT. CBL, cement supplier is PT. SAS, and natural material supplier is PT. Citra BSD.

\section{CONCLUSIONS}

XYZ companies rely heavily on suppliers for project sustainability, so that no delays are caused by the improper selection of suppliers. To determine some concerns about choosing the right supplier, one of them is using AHP method. Because AHP method is a method by which the main input is human perception [11]. Based on the overall results of data processing and assessment analysis conducted on the selection of the main material suppliers in the contractor company is PT. XYZ using the Analytical Hierarchy Process (AHP) method can be concluded on the results of the research, 
which is the answer to the problem in the study, as follows: There are 4 criteria used in this study, the highest weight criteria that can be the company's reference in choosing a supplier is quality (weight of $29 \%$ ), hereinafter the cost (interest $26.8 \%$ ), delivery (weight of interest 24.8\%) and services (weight of interest $19.4 \%$ ).. Selected quality criteria based on the ability to provide consistent quality of each supplier. After that new criteria consider the cost, delivery and service. It is very important to minimize the delay of project completion.

Data analysis result from AHP calculation, obtained using a questionnaire of 5 respondents, stating that the alternative selection of each main material selected and best according to the criteria, for iron suppliers is PT. CBL, cement supplier is PT. SAS, and natural material supplier is PT. Citra BSD.

XYZ Company relies heavily on suppliers to the sustainability of the project, therefore it is recommended that the company make improvements in the selection of suppliers that were previously based solely on the direct designation, after which the authors do this research company can apply AHP method with Expert Choice software to choose good and qualified supplier according to the criteria that the company wants.

\section{REFERENCES}

1. Akbar, P. G., Henmaidi, H., \& Amrina, E. (2016). Usulan Indikator Evaluasi Pemasok Dalam Penetapan Bidder List: Studi Kasus Pengadaan Jasa PT. Semen Padang. Jurnal Optimasi Sistem Industri, 14(1), 39-54.

2. Ávila, P., Mota, A., Pires, A., Putnik, G., \& Teixeira, J. (2012). Supplier's selection model based on an empirical study. Procedia Technology, 5, 625634.

3. Bai, C., \& Sarkis, J. (2010). Integrating sustainability into supplier selection with grey system and rough set methodologies. International Journal of Production Economics, 124(1), 252-264.
4. Büyüközkan, G., Çifçi, G., \& Güleryüz, S. (2011). Strategic analysis of healthcare service quality using fuzzy AHP methodology. Expert systems with applications, 38(8), 9407-9424.

5. Dickson, G. W. (1966). An analysis of vendor selection systems and decisions. Journal of purchasing, 2(1), 5-17.

6. Golmohammadi, D., \& Mellat-Parast, M. (2012). Developing a grey-based decision-making model for supplier selection. International Journal of Production Economics, 137(2), 191-200.

7. Handfield, R., Walton, S. V., Sroufe, R., \& Melnyk, S. A. (2002). Applying environmental criteria to supplier assessment: A study in the application of the Analytical Hierarchy Process. European journal of operational research, 141(1), 70-87.

8. Mirmousa, S., \& Dehnavi, H. D. (2016). Development of criteria of selecting the supplier by using the fuzzy DEMATEL method. ProcediaSocial and Behavioral Sciences, 230, 281-289.

9. Nydick, R. L., \& Hill, R. P. (1992). Using the analytic hierarchy process to structure the supplier selection procedure. International Journal of purchasing and materials management, 28(2), 3136.

10. Saaty, T. L., \& Kearns, K. P. (1985). Analytical Planning the Organization of Systems. Pergamon Press.

11. Saaty, T. L. (1994). Fundamentals of Decision Making and Priority Theory, RWS Publications, Pittsburgh.

12. Saaty, T.L. (2005). Theory and Applications of the Analytic Network Process: Decision Making with Benefits, Opportunities, Costs, and Risks. RWS Publications, USA.

13. Stevenson, William, J. (2018). Operations Management. McGraw-Hill. New York.

14. Taylor, B. W. (2010). Introduction to Management Science, 10th ed, Prentice Hall, New Jersey.

15.Zhang, X., Deng, Y., Chan, F. T., Adamatzky, A., \& Mahadevan, S. (2016). Supplier selection based on evidence theory and analytic network process. Proceedings of the institution of Mechanical Engineers, Part B: Journal of Engineering manufacture, 230(3), 562-573. 